\title{
Glulam-concrete Composites: Experimental Investigation into the Connection System
}

\author{
José Luiz Miotto ${ }^{\mathrm{a} *}$, Antonio Alves Dias \\ ${ }^{a}$ State University of Maringá, Av. Colombo, 5.790, CEP 87.020-900, Maringá, PR, Brazil \\ ${ }^{\mathrm{b}}$ ão Carlos School of Engineering, University of São Paulo, \\ Av. Trabalhador São-carlense, 400, CEP 13566-590, São Carlos, SP, Brazil
}

Received: October 5, 2010; Revised: December 19, 2010

\begin{abstract}
Timber-concrete composite structures work appropriately when a suitable connection system is included because the degree of interaction between the materials stiffs the structural system. Thereby, it is extremely important to improve the knowledge about their connection system. The purpose of this paper is to show the results obtained by experimental investigation into push-out shear tests of glulam-concrete specimens. The specimens were designed to simulate the behaviour of composite $\mathrm{T}$ beams and the connection system was constituted by steel hooks - got by the division of steel bars used in reinforced concrete members - and by perforated steel plates, both glued with epoxy adhesive. They were tested under shear forces with constant loading rate. Six specimens of each group were made, considering two different diameters for the hooks ( 8 and $10 \mathrm{~mm}$ ) and $4.75 \mathrm{~mm}$ thick perforated steel plates. The stiffness reached by steel hooks confirms their suitability for the use in composite timber-concrete systems.
\end{abstract}

Keywords: glulam-concrete composites, connection system, experimental investigation, push-out shear tests

\section{Introduction}

Nowadays, wood originated from rainforest has become increasingly scarce. This shortage contributes to the development of alternatives that consider the rational use of timber and the application of reforestation species, especially the pinus and eucalyptus. In this context, timber-concrete composite structures have been used with success in bridge structures and in floors of residential, industrial and sporting buildings, finding spaces for application in structural repairs of historical buildings and in new constructions. To reduce the dimensional limitations of timber, among other characteristics, it is possible to use glued laminated timber (glulam) pieces instead of sawn wood or logs in this composition.

It is indispensable the adoption of an appropriate connection system for an efficient timber-concrete composite structure. The connectors assure the transfer of shear forces and also avoid the vertical separation between the parts. Steel connectors, in different shapes, are usually used as connection elements.

This work focuses on the flexible connection systems, particularly those that are constituted by hooks - obtained by the division of steel bars used in reinforced concrete (rebar) - and by perforated flat steel plates. The results obtained from the push-out shear tests are presented here and the tests were made in specimens specially designed for this purpose.

\section{Timber-Concrete Composite Structures}

The expressive number of scientific publications on behavior of timber-concrete composite structures, around the world, confirms the interest of researches in this subject. In Miotto ${ }^{1}$ it is shown a compilation of publications - in Brazil and other countries - on the subject in recent decades. Also, in the following paragraphs, it is exhibited some contemporary and important researches on the theme.

*e-mail: jlmiotto@uem.br
Timber-concrete composite systems are becoming more popular because they can exploit the best qualities of the involved materials. In fact, the timber is positioned in the tension region of the composite section while the concrete is used practically in the compression zone, attaining the best performance of these materials in terms of strength and stiffness. Thereby it is possible to obtain a cross section structurally efficient, being rigid and light at same time.

The structural performance of timber-concrete composite systems is a reason that draws the attention of researchers. In Ceccotti ${ }^{2}$ it is affirmed that the load carrying capacity of a traditional timber floor can be doubled and its out-of-plane rigidity improved three or four times when the timber-concrete composite system is applied. Additionally Davids ${ }^{3}$ points out that, when compared with noncomposite timber-concrete girders, the bending strength increases at least $40 \%$ and it is commonly reported increases of $200 \%$ or more in the service-load stiffness for timber-concrete beams with partially composite concrete decks.

Gutkowski et al. ${ }^{4}$ conducted tests on timber-concrete composite beams to determine the degree of partial composite action between the materials, for a particular kind of connector. The test results showed that it is possible to achieve medium to high degrees of composite action in layered timber-concrete beams. These results confirm that the timber-concrete composite system has a profile that qualifies it for use in modern engineering works.

\subsection{Connection system}

Timber-concrete composite beams work appropriately when an appropriate system of connection is included between the two materials, because their interaction stiffs the structural system. There is a great variety of elements that can be used for this purpose, such as those showed by Ceccotti ${ }^{2}$. 
The strength and ductility of the connectors are experimentally obtained. For this purpose it has been frequent the use of push-out shear test specimens, as shown in Figure 1. In Brazil there is not normalization for this kind of test. So, it is noticed that the researchers accomplish adaptations in the dimensions and configurations of the model, sometimes placing the concrete in the inside part of the specimen and, other times, inverting that arrangement. In Molina et al. ${ }^{5}$ it is described the experimental analysis carried out to evaluate the pullout strength and axially loaded steel rods used as connector elements in log-concrete composite bridge decks. In this case, there are no concrete elements on specimen arrangement.

Carvalho and Mantilla Carrasco ${ }^{6}$ conducted experimental investigation to determine the influence of the specimen arrangement in the strength and deformation characteristics of timber-concrete composite joints. It was observed that the specimen with the best strength was the concrete-wood-concrete type, similar to those used in steel-concrete composite structures.

Starting from experimental results, Oehlers and Bradford ${ }^{7}$ comment that the geometry and layout of the specimen can have significant influence in the resistance of the connectors. They highlight three parameters: height (h) of the connectors above the base, number of connectors per level and the way of linking the specimen to the base.

The connection system can be made in an easy and economical way by gluing - usually using epoxy adhesive - pieces of steel bars in holes previously executed, which can be positioned perpendicular to the grain or with some inclination. When the connectors are positioned alternately and with some inclination the system is called connection "in X". According to Pigozzo ${ }^{8}$, this connection system presents stiffness two or three times larger when compared to the perpendicular connectors, depending on the diameter.

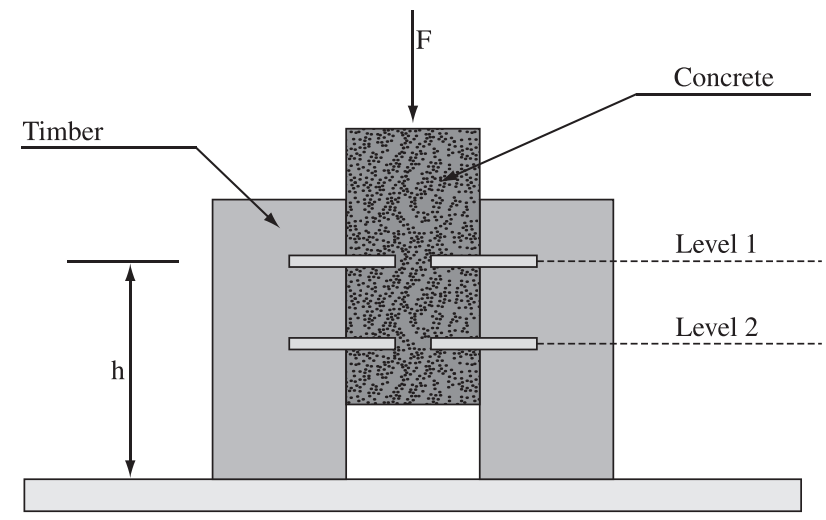

Figure 1. View of a traditional specimen used in push-out shear tests.

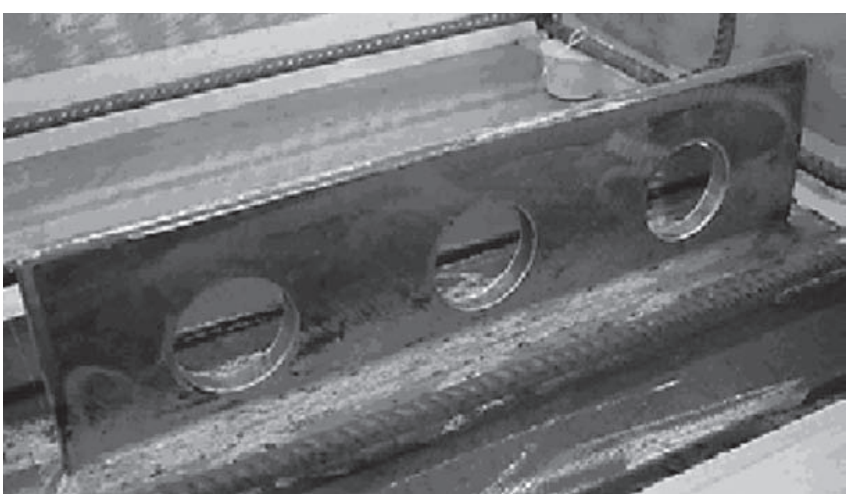

Figure 2. Connector type perfobond. Source: Valente and $\mathrm{Cruz}^{9}$.
With the intention of making the connection between steel beams and concrete slabs, a connection element was developed in the eighties. This connector was constituted by a perforated steel plate, also known as perfobond (Figure 2). The "concrete pins" that are formed through the holes, associated with steel bars arranged in the transverse direction, supply shear strength and hold the joined materials. The shear strength of connectors formed by perforated steel plates is usually high, regardless of the shape and size of holes. Thereby, this connector can become an efficient alternative for timberconcrete composite structures.

\subsection{Slip modulus}

To evaluate the behavior of connectors, in composite systems, it is used the slip modulus, $K$, that is defined as the angular coefficient of the load-slip curve and obtained by means of specimens that represent the connection, with real dimensions. This coefficient considers all the elastic and mechanical parameters of the materials involved in the connection, such as: dimensions and stiffness of connectors, stiffness and embedding strength of the timber used, concrete embedding and cracking, besides all the imperfections of the specimen.

To obtain this parameter, Ceccotti ${ }^{2}$ proposed a model based on the indications of EUROCODE $4^{[10]}$, which defines the slip modulus of service, $K_{\mathrm{ser}}$, corresponding to the initial levels of loading, and the ultimate slip modulus, $K_{\mathrm{u}}$. The $K_{\mathrm{ser}}$ value is obtained by the inclination of the secant straight line that cross the beginning of the load-slip curve and the point corresponding to $40 \%$ of the rupture load, with its respective slipping. In agreement with EUROCODE $5^{[11]}$, the ultimate slip modulus is calculated according to Equation 1:

$$
K_{u}=\frac{2}{3} K_{\text {ser }}
$$

Pigozzo $^{8}$ emphasizes that, in the slip modulus determination, the limits that are used for the evaluation vary a lot among authors and normative codes. Thereby, this can result in significant variations in calculated values by different researchers.

For pins fixed perpendicularly to the grain, the slip modulus of service is calculated by Equation 2, based on the indications of EUROCODE $5^{[11]}$, which takes into account the equivalent density of the materials, in kg. $\mathrm{m}^{-3}$, according to Equation 3, and the diameter of the pins, in mm. However, according to this normative code, for connections between timber and concrete, $K_{\text {ser }}$ must be multiplied by 2 .

$$
\begin{aligned}
& K_{s e r}=\frac{\rho_{k}^{1,5} \cdot \varphi}{23} \quad \text { with } \\
& \rho_{k}=\sqrt{\rho_{k 1} \cdot \rho_{k 2}}
\end{aligned}
$$

\section{Materials and Methods}

To evaluate the performance of the connectors into timberconcrete composite system was developed an experimental program constituted by the following steps: a) characterization of the involved materials and b) determination of the slip modulus, $K_{\text {ser }}$, for all proposed connection systems. All the tests were carried out at the laboratories of the Department of Structures, at São Carlos School of Engineering - University of São Paulo, Brazil.

\subsection{Push-out shear tests: description of the specimens}

The values of slip modulus of service and rupture loads, corresponding to each connection system, were determined by means of push-out shear tests. Specimens were especially designed with the expectation of reproducing the solicitations that will be experienced for the connectors in glulam-concrete composite beams. 
Specimens type SP-I and SP-II, showed in Figure 3, had the connection system composed by steel hooks, which were obtained from the division of corrugated steel bars used for reinforced concrete (rebar). Firstly, the hooks were glued in glulam pieces by means of epoxy adhesive (compound gel adhesive, bicomponent, high fluidity, manufactured by Otto Baumgart), in holes previously drilled and whose diameters are given in Table 1 . The adhesive was inserted into the hole by means of a plastic syringe with a thin silicone tube adapted at its tip. The anchorage length of the hooks in glulam - equivalent to $11 \mathrm{~d}$ and also given in Table 1 - are based on results of Ahmadi and $\mathrm{Saka}^{12}$. Six specimens were made for each group of connectors. Figure 4 shows the concrete pouring phase.

The hooks were attached with an inclination of $45^{\circ}$ in relation to the grain, being submitted, in this case, mainly to tension forces. Results obtained by Pigozzo $^{8}$ justify this type of positioning.

The specimens also hold two side pieces made of reinforced concrete, cast in situ, which have the function of providing stability to the set. To prevent surface cracking of the concrete it was layed a steel mesh reinforcement $(10 \times 10 \mathrm{~cm})$, which the bars had $4.2 \mathrm{~mm}$ in diameter and the steel had characteristic yield strength of $600 \mathrm{MPa}$. Figure 5 shows the placement of the steel mesh in the concrete side piece.

In Figures 6 and 7 are shown details of the specimens type SPIII. In this case, the connection system was constituted by perforated steel plates. Firstly, it was made openings with $6 \mathrm{~mm}$ thick along both sides of glulam pieces. Then, the flat steel plates - with $4.75 \mathrm{~mm}$ thickness - were glued to the glulam with the same epoxy adhesive used for gluing the hooks. In the same way as in specimens type SP-I and SP-II, the side pieces of concrete also received a layer of mesh reinforcement, as previously mentioned. Six specimens also were produced for this group.

\subsection{Materials and properties}

The wood used for making the glulam pieces - that constitute the central part of the specimens - was a hybrid of Eucalyptus grandis
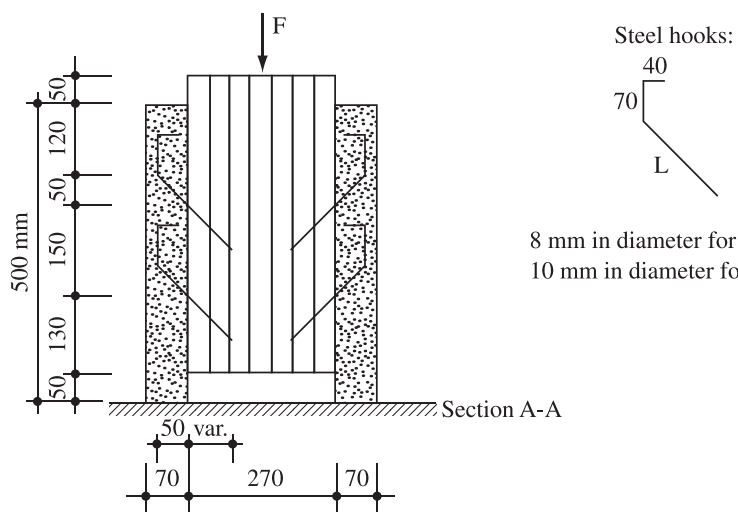

$\mathrm{mm}$ in diameter for SP - I $10 \mathrm{~mm}$ in diameter for SP - II

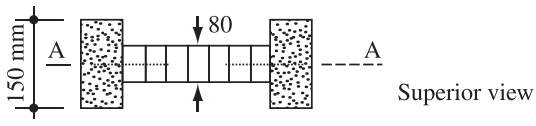

Figure 3. Specimens type SP-I and SP-II.

Table 1. Characteristics of hooks.

\begin{tabular}{cccc}
\hline $\begin{array}{c}\text { Specimen } \\
\text { type }\end{array}$ & $\begin{array}{c}\text { Diameter } \\
\text { of hook } \\
(\mathrm{mm})\end{array}$ & $\begin{array}{c}\text { Diameter } \\
\text { of hole } \\
(\mathrm{mm})\end{array}$ & $\begin{array}{c}\text { Anchorage length } \\
\text { in glulam } \\
(\mathrm{mm})\end{array}$ \\
\hline SP-I & 8 & 10.0 & 88 \\
SP-II & 10 & 12.5 & 110 \\
\hline
\end{tabular}

and Eucalyptus urophylla, which is sold in Brazil with the name of Lyptus. According to recommendations of NBR $7190^{[13]}$, the wood was tested and exhibited the following results: average moisture content of $9.1 \%$ and apparent density $\rho_{\mathrm{ap}, 12 \%}=0.79 \mathrm{~g} \cdot \mathrm{cm}^{-3}$.

From the glulam pieces were also extracted specimens to obtain the mechanical properties of the material, being found the following average values corresponding to $12 \%$ of moisture content: compression strength parallel to grain $-\mathrm{f}_{\mathrm{c}, 0}=69.4 \mathrm{MPa}$; tension strength parallel to grain $-\mathrm{f}_{\mathrm{t}, 0}=82.9 \mathrm{MPa}$; shear strength in the glue interface $-\mathrm{f}_{\mathrm{v}, 0}=7.7 \mathrm{MPa}$; bending strength $-\mathrm{f}_{\mathrm{M}}=103.8 \mathrm{MPa}$; embedding strength $-\mathrm{f}_{\mathrm{h}, 0}=60.9 \mathrm{MPa}$ and modulus of elasticity in bending $-\mathrm{E}_{\mathrm{M}}=18,004 \mathrm{MPa}$. All these tests were carried out in conformity with the recommendations of Annex B of NBR 7190 ${ }^{[13]}$.

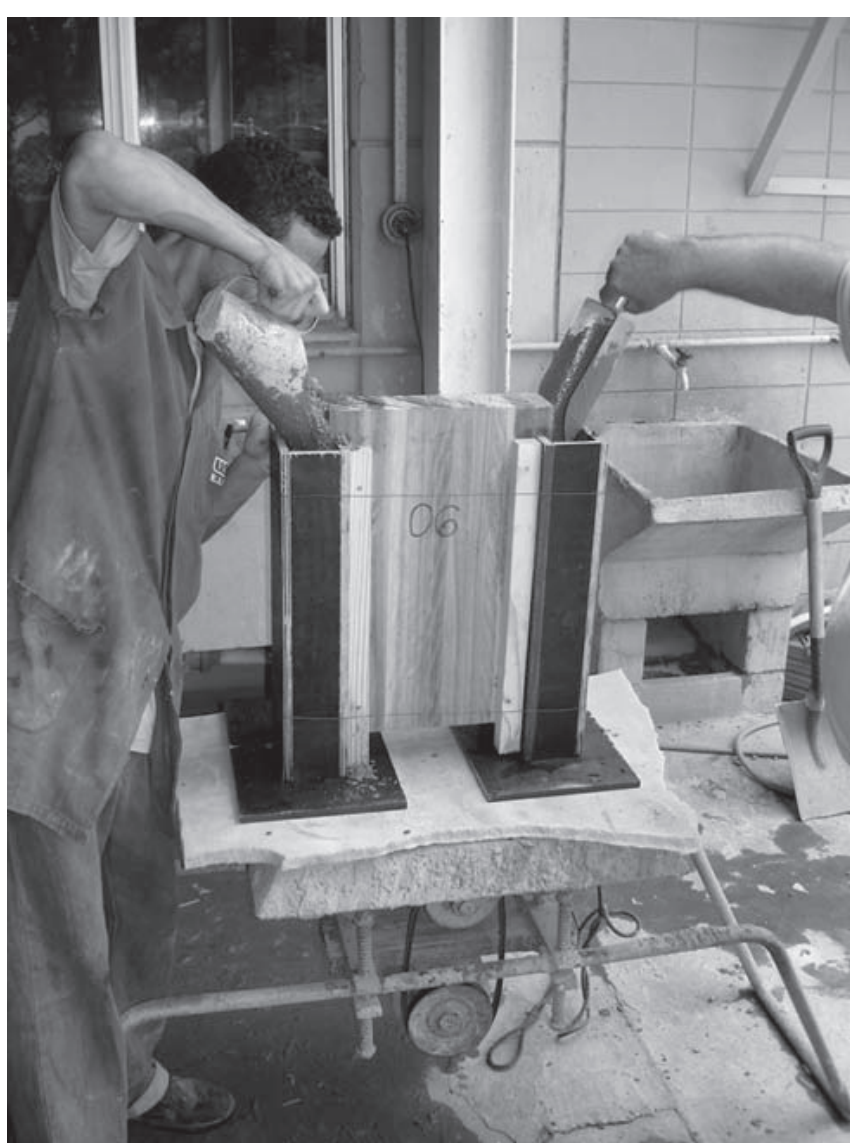

Figure 4. Concrete being poured in specimen.

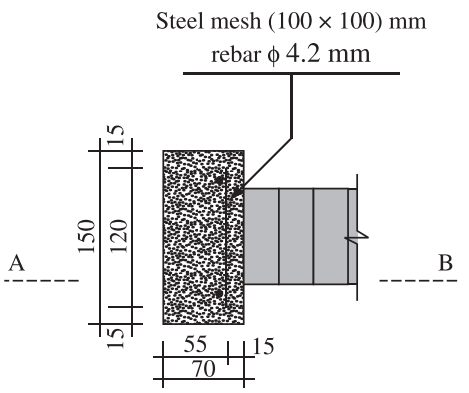

Plan view

measures in milimeter

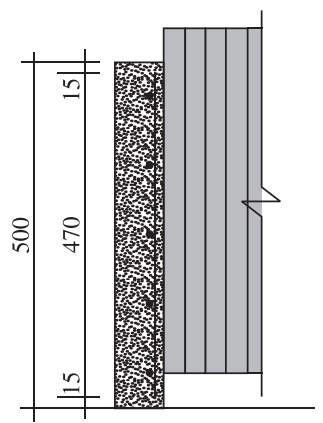

Section $\mathrm{AB}$

measures in milimeter

Figure 5. Placement of the steel mesh in the concrete side piece of specimens. 
After the machining of wood, the laminations resulted in approximately $80 \mathrm{~mm}$ width and $30 \mathrm{~mm}$ thickness. Fingerjoints were made into the laminations before the production of the glulam beams, because glulam beams had $5.4 \mathrm{~m}$ length and the laminations had a maximum length of $3 \mathrm{~m}$. In the production of glulam beams was applied a pressure of 1.0 MPa in the laminations, through a system consisting of hydraulic pistons. These beams were cut, later, for the fabrication of the specimens. The beams and the fingerjoints were produced from the use of an aqueous emulsion polymer isocyanate adhesive - Wonderbond EPI EL 70, made in Brazil.

From the prepared concrete for production of the specimens was extracted enough amount of material to mold twelve cylindrical specimens $(15 \times 30 \mathrm{~cm})$, from which were obtained the following
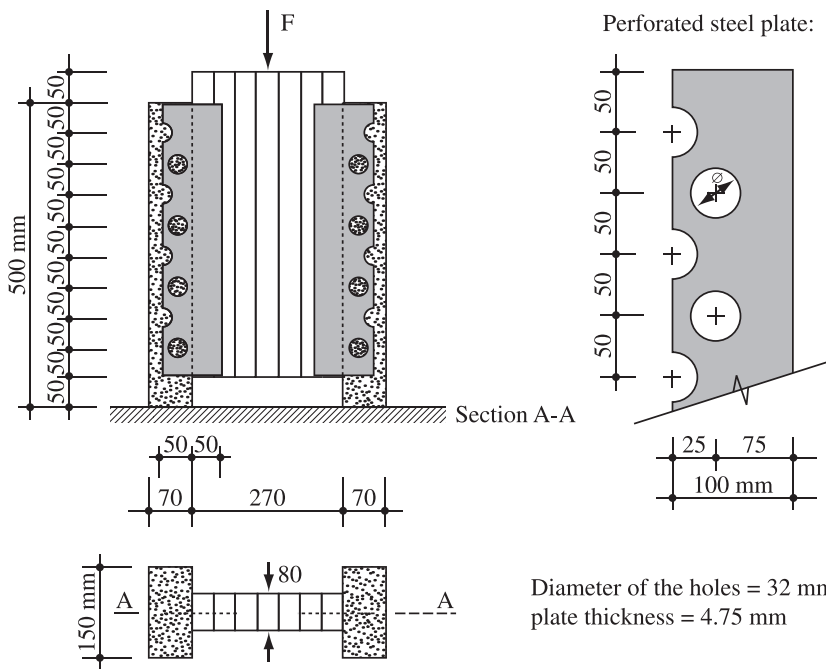

Diameter of the holes $=32 \mathrm{~mm}$ plate thickness $=4.75 \mathrm{~mm}$

Superior view

Figure 6. Details of specimens type SP-III.

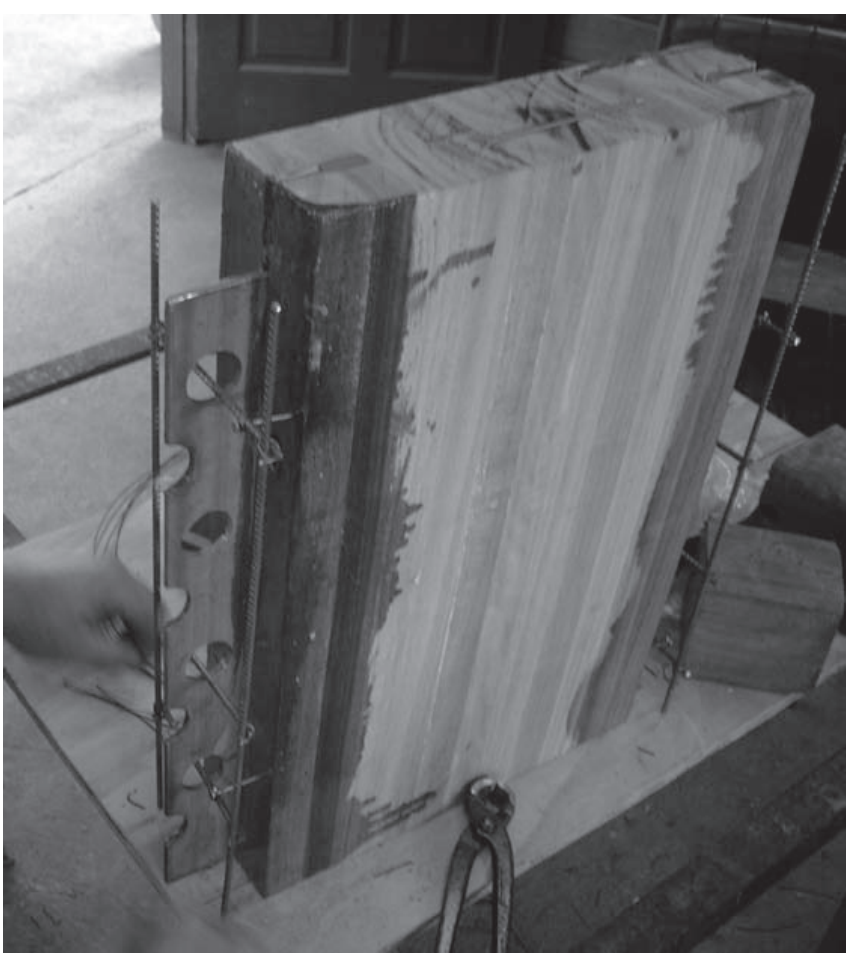

Figure 7. Specimens type SP-III being constructed. average values: compression strength $(28$ days $)-f_{c 28}=33.9 \mathrm{MPa}$ and modulus of elasticity (initial tangent) $\mathrm{E}=31,358 \mathrm{MPa}$. The specimens were molded according to NBR $5738^{[14]}$ and the tests were carried out in conformity with the codes NBR $5739^{[15]}$ and NBR $8522^{[16]}$.

The hooks that were used as connection system were produced from steel bars - whose characteristic yield strength, $\mathrm{f}_{\mathrm{yk}}$, is $500 \mathrm{MPa}$ - with nominal diameters of 8 and $10 \mathrm{~mm}$. The perforated steel plates, also used as connectors, were obtained by cutting flat steel plates with $4.75 \mathrm{~mm}$ thickness. It is important to point out that these connectors must be galvanized when applied in composite structures.

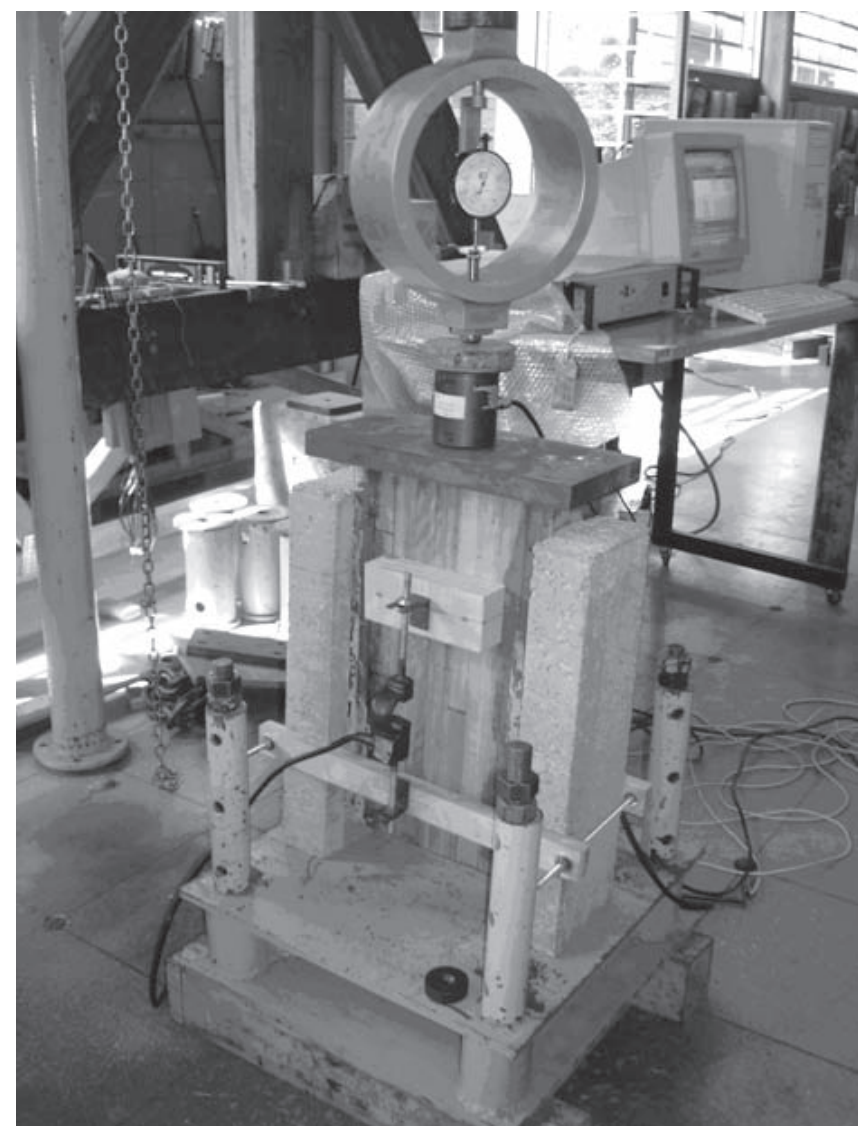

Figure 8. Test arrangement and data acquisition.

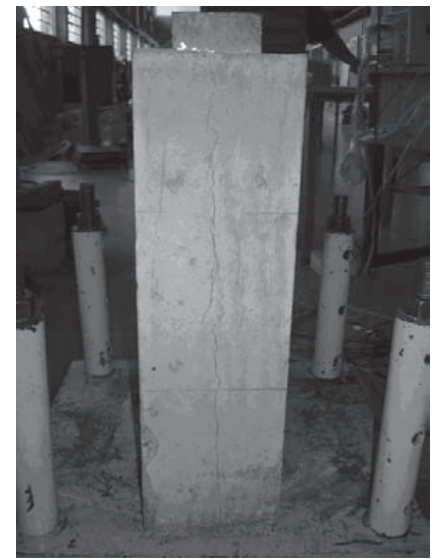

(a)

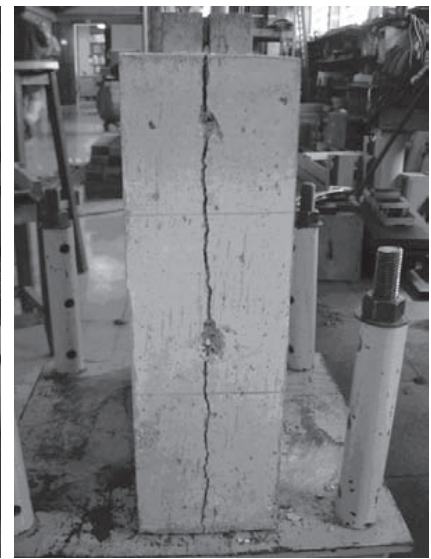

(b)
Figure 9. a) Typical rupture for SP-I and SP-II and b) typical rupture for SP-III. 


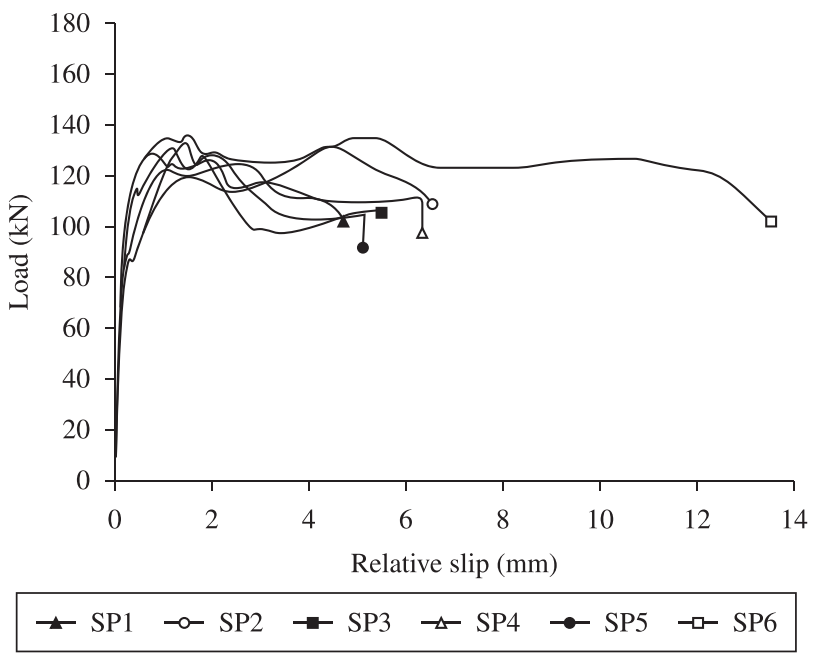

Figure 10. Load-slip relationship for specimens type SP-I.

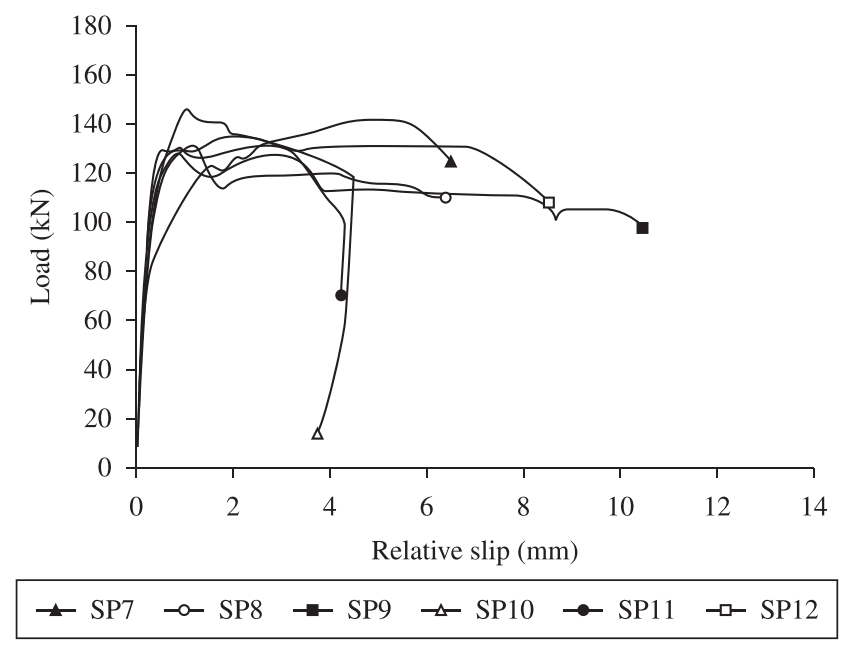

Figure 11. Load-slip relationship for specimens type SP-II.

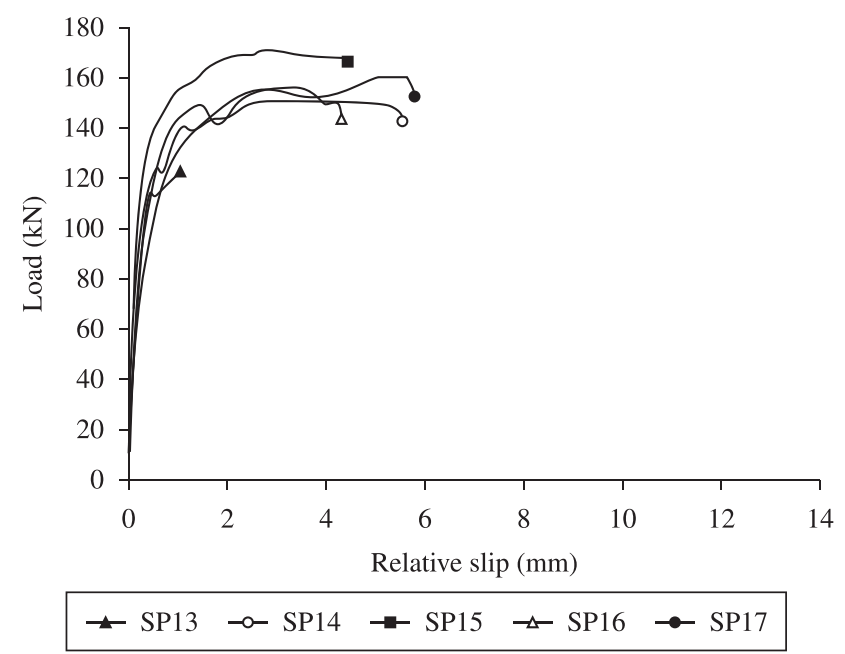

Figure 12. Load-slip relationship for specimens type SP-III.

\subsection{Testing procedures}

The specimens were submitted to constant rate of loading, equivalent to $0.6 \mathrm{MPa} / \mathrm{min}$, in a cycle constituted of loading and unloading, and, after that, subjected to loading until to reach the collapse. Equipments were installed, as shown in Figure 8, for the acquisition of the following data: a) applied loads; b) slips in the timber-concrete interface; and c) rupture loads.

The slips in the glulam-concrete interface were obtained through measurement instruments manufactured by Kyowa Electronic Instruments, which were installed in opposite faces of the specimens. In the upper end of the specimens was installed a load cell with capacity for $250 \mathrm{kN}$. Finally, all the instruments were connected to a system for data acquisition - System 5000 of Vishy Measurements Groups.

Table 2. Results of specimens type SP-I.

\begin{tabular}{ccc}
\hline Specimen & $\begin{array}{c}\text { Ultimate load } \\
(\mathrm{kN})\end{array}$ & $\begin{array}{c}\text { Slip modulus } K_{\text {ser }} \\
\left(\mathrm{N}_{\mathrm{mm}}^{-1}\right)\end{array}$ \\
\hline SP1 & 124.5 & 145,729 \\
SP2 & 131.2 & 131,679 \\
SP3 & 135.6 & 181,395 \\
SP4 & 126.2 & 111,608 \\
SP5 & 133.0 & 135,438 \\
SP6 & 135.7 & 151,769 \\
\hline Average & 131.0 & 142,936 \\
Standard deviation & 4.3 & 21,328 \\
cov (\%) & 3.3 & 14.9
\end{tabular}

Table 3. Results of specimens type SP-II.

\begin{tabular}{ccc}
\hline Specimen & $\begin{array}{c}\text { Ultimate load } \\
(\mathrm{kN})\end{array}$ & $\begin{array}{c}\text { Slip modulus } K_{\text {ser }} \\
\left(\mathrm{N}^{\left.-\mathrm{mm}^{-1}\right)}\right.\end{array}$ \\
\hline SP7 & 142.1 & 143,109 \\
SP8 & 131.7 & 108,619 \\
SP9 & 129.7 & 132,039 \\
SP10 & 145.5 & 112,778 \\
SP11 & 130.8 & 84,463 \\
SP12 & 131.7 & 96,982 \\
\hline Average & 135.3 & 112,998 \\
Standard deviation & 6.2 & 19,829 \\
cov (\%) & 4.6 & 17.6
\end{tabular}

Table 4. Results of specimens type SP-III.

\begin{tabular}{ccc}
\hline Specimen & $\begin{array}{c}\text { Ultimate load } \\
(\mathrm{kN})\end{array}$ & $\begin{array}{c}\text { Slip modulus } K_{\text {ser }} \\
\left(\mathrm{N}^{\left.-m^{-1}\right)}\right.\end{array}$ \\
\hline SP13 & 123.6 & 594,482 \\
SP14 & 156.3 & 355,251 \\
SP15 & 171.7 & 347,276 \\
SP16 & 155.2 & 221,853 \\
SP17 & 160.2 & 178,169 \\
\hline Average & 153.4 & 339,406 \\
Standard deviation & 16.0 & 145,047 \\
cov (\%) & 10.5 & 42.7
\end{tabular}


Table 5. Behaviour of connection systems.

\begin{tabular}{|c|c|c|c|c|}
\hline $\begin{array}{l}\text { Specimen } \\
\text { type }\end{array}$ & Connection & $K_{s e r}\left(\mathrm{~N}_{[1]} \mathrm{mm}^{-1}\right)$ & $\begin{array}{c}K_{s e r}-\text { Eurocode } 5\left(\mathrm{~N} \cdot \mathrm{mm}^{-1}\right) \\
{[2]}\end{array}$ & $\frac{[1]}{[2]}$ \\
\hline SP-I & Hooks $-\varnothing 8 \mathrm{~mm}$ & 142,936 & 35,206 & 4.1 \\
\hline SP-II & Hooks $-\varnothing 10 \mathrm{~mm}$ & 112,998 & 44,008 & 2.6 \\
\hline SP-III & Perforated plates - \# $4.75 \mathrm{~mm}$ & 339,406 & - & - \\
\hline
\end{tabular}

\section{Results and Discussion}

During the tests, the specimens showed an excellent behaviour relatively to stability. It was perceptible the cracking of concrete - particularly along the line that contains the connectors, as it are shown in Figures $9 \mathrm{a}$ and $\mathrm{b}$ - and in the proximities of the connectors. The predominant way of rupture was the cracking of the concrete particularly in the line that contains the connectors - accompanied by a sharp bending of the hooks.

In tests previously carried out, it was found that the use of epoxy adhesive with high consistence caused considerable difficulty for gluing the connectors. On the other hand, the epoxy adhesive used in the production of these specimens, because of having a fluid consistency, it reached fully its aim. It was not observed any detachment of hooks or perforated plates during the tests.

The behaviour of specimens type SP-I, SP-II and SP-III are shown in Figures 10, 11 and 12. Additionally, the results of tests are listed in Tables 2, 3 and 4.

The data relative to test of one specimen type SP-III were lost, being just registered the values relative to the load of rupture and the relative slips corresponding to the this load.

In Table 5 it is registered the behavior of the connection systems proposed in this research, with their respective average values of slip moduli (initial stiffnesses). To calculate the slip modulus of service it was considered as rupture load the maximum value admitted by a specimen. For comparison, in the last column are shown the values of slip moduli calculated according to recommendations of EUROCODE $5^{[11]}$, which are valid for pins fixed perpendicular to the grain.

Connectors with $8 \mathrm{~mm}$ in diameter, attached to the glulam with an inclination of $45^{\circ}$ in relation to the grain and with the geometric configuration proposed in this research, present an initial slip modulus 4.1 times greater than those connectors fixed perpendicularly to the grain (whose slip modulus of service was calculated according to EUROCODE $5^{[11]}$ ), as shown in Table 5. This comparison has the effect of highlighting the best performance of connectors fixed at $45^{\circ}$ in relation to the grain.

Also it is possible to identify, in Table 5, that the hooks with diameter of $8 \mathrm{~mm}$ reached a larger average value of $K_{\text {ser, }}$, when compared to the hooks with $10 \mathrm{~mm}$ in diameter. A hypothesis to explain this fact is related to the anchorage of those hooks in the concrete. It was also noticed that the specimens type SP-III presented small slips in the glulam-concrete interface, what resulted in a high slip modulus. Nevertheless, one specimen from this group had an abrupt collapse (fragile rupture) and this behavior, in general, is not very interesting for structural members.

After the tests, the concrete was removed and it was not observed any embedding of the timber in contact with the hooks. Also it is important to mention that glulam pieces had an excellent performance during the tests and was not observed any delamination or splitting in the glued surfaces.

Pigozzo $^{8}$ obtained the initial slip modulus for connectors with $8 \mathrm{~mm}$ in diameter, attached at $45^{\circ}$ in relation to the grain, by means of push-out shear tests, with the following additional characteristics: anchorage length of $76 \mathrm{~mm}$; characteristic yield strength of steel $-\mathrm{f}_{\mathrm{yk}}=500 \mathrm{MPa}$; fluid epoxy adhesive (Sikadur 32); Eucalyptus citriodora with average moisture content of 14\%, CCA-treated; compression strength of concrete ( 28 days) $-\mathrm{f}_{c, 28}=26 \mathrm{MPa}$ and connectors subjected predominantly to tensile forces. The average value of $K_{\text {ser }}$ obtained was equivalent to $47.98 \mathrm{kN} . \mathrm{mm}^{-1}$.

Thus, from the geometric configuration and conditions proposed in this research, it was obtained a slip modulus of service three times higher than the value obtained by Pigozzo ${ }^{8}$. The geometric configuration of the hook evaluated in this study may be a probable explanation for the observed differences in results, because the connectors proposed by Pigozzo ${ }^{8}$ bend at only one point along its length. On the other hand, the connectors proposed by Pigozzo ${ }^{8}$ are easier to be made.

\section{Conclusions}

Undoubtedly timber-concrete composite structures have a vast field of applications in constructions. The excellent structural performance, associated with other advantages, allow their use in refurbishment of historical buildings and in new constructions. To enlarge the domain of applications of timber-concrete composite systems, an important alternative consists in the replacement of logs or sawn timber for glulam pieces, which offer the requested dimensional freedom and motivate the use of timber coming from planted forests.

This composite system works appropriately when the right connectors are included between the materials, which impede the separation between the parts and also stiff the structural system. There is a great variety of elements that can be used for this purpose. However, the flexible connections occupy a prominence place due to their versatility and low cost.

The performance of connection systems is evaluated experimentally - in actual size models - and their respective slip modulus are calculated. In this work eighteen specimens were built, divided in three groups, whose connectors were obtained by the division of corrugated steel bars and by cutting perforated steel plates. Test results indicated that steel hooks demonstrate efficiency for this connection system. It is noticed that the diameter of hooks has influence on their respective slip modulus of service. Hooks with $8 \mathrm{~mm}$ in diameter showed a slip modulus of service equivalent to $142.9 \mathrm{kN} \cdot \mathrm{mm}^{-1}$.

Besides the diameter of the connector, other characteristics have an elevated influence on initial slip modulus, as the geometric configuration. An increase in the anchorage length of the hooks into concrete can make the system three times stiffer to slip, as demonstrated in this work.

On the other hand, the perforated steel plates are more efficient in terms of initial stiffness, with high slip modulus when compared to the values obtained for the hooks. In spite of the high slip modulus reached by the perforated plates, they don't experiment large plastic deformations. 


\section{Acknowledgements}

The authors thank the Conselho Nacional de Desenvolvimento Científico e Tecnológico - CNPq - for the financial resources provided for this work.

\section{References}

1. Miotto JL. Estruturas mistas de madeira-concreto: avaliação das vigas de madeira laminada colada reforçadas com fibras de vidro (Timberconcrete composite structures: evaluation of GFRP reinforced glulam beams). [Thesis - Doctorate in Structural Engineering]. São Carlos: São Carlos School of Engineering, University of São Paulo; 2009.

2. Ceccotti A. Timber-concrete composite structures. In: Blass HJ, editor. Timber engineering - STEP 2. Structural Timber Education Programme. The Netherlands: Centrum Hout; 1995. p. E13/1-E13/12.

3. Davids WG. Nonlinear analysis of FRP-glulam-concrete beams with partial composite action. Journal of Structural Engineering, ASCE. 2001; 127(8):967-971.

4. Gutkowski R, Brown K, Shigidi A and Natterer J. Laboratory tests of composite wood-concrete beams. Construction and Building Materials. 2008; 22:1059-1066

5. Molina JC, Calil Junior C and Carreira MR. Pullout strength of axially loaded steel rods bonded in glulam at a $45^{\circ}$ angle to the grain. Materials Research. 2009; 12(4):427-432.

6. Carvalho EP and Mantilla Carrasco EV. Influence of test specimen on experimental characterization of timber-concrete composite joints. Construction and Building Materials. 2010; 24:1313-1322.

7. Oehlers DJ and Bradford MA. Composite steel and concrete structural members: fundamental behavior. Oxford: Elsevier Science; 1995.
8. Pigozzo JC. Estudos e aplicações de barras de aço coladas como conectores em lajes mistas de madeira e concreto para tabuleiros de pontes (Studies and applications of steel bars glued as connectors in timber-concrete composite slabs for bridge decks). [Thesis - Doctorate in Structural Engineering]. São Carlos: São Carlos School of Engineering, University of São Paulo; 2004.

9. Valente I and Cruz PJS. Experimental analysis of Perfobond shear connection between steel and lightweight concrete. Journal of Constructional Steel Research. 2004; 60:465-479.

10. European Prestandard. Design of composite steel and concrete structures. Brussels, Belgium: European Committee for Standardization; 1994. Draft for development. (EUROCODE 4, Part 1).

11. European Prestandard. Design of timber structures. Brussels, Belgium: European Committee for Standardization; 2004. (EUROCODE 5, Part 1-1).

12. Ahmadi BH and Saka MP. Behaviour of composite timber-concrete floors. Journal of Structural Engineering, ASCE. 1993; 10:3111-3130.

13. Associação Brasileira de Normas Técnicas - ABNT. NBR 7190: Projeto de estruturas de madeira (Design of timber structures). Rio de Janeiro; 1997.

14. Associação Brasileira de Normas Técnicas - ABNT. NBR 5738: Concreto - Procedimento para moldagem e cura de corpos-de-prova (Concrete Proceedings for molding and curing of specimens). Rio de Janeiro; 2003.

15. Associação Brasileira de Normas Técnicas -ABNT. NBR 5739: Concreto - Ensaio de compressão de corpos-de-prova cilíndricos (Concrete Compression tests in cylindrical specimens). Rio de Janeiro; 1994.

16. Associação Brasileira de Normas Técnicas-ABNT. NBR 8522: Concreto - Determinação dos módulos estáticos de elasticidade e de deformação e da curva tensão-deformação (Concrete - Determination of static and strain elasticity modulus and of stress-strain curve). Rio de Janeiro; 2003. 